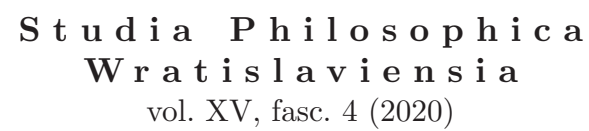

https://doi.org/10.19195/1895-8001.15.4.2

\author{
DAMIAN WINCZEWSKI \\ ORCID: 0000-0003-0809-4817 \\ badacz niezależny
}

\title{
Dialektyka wiedzy logikomatematycznej w ujęciu Jarosława Ladosza
}

\section{Jarosław Eadosz on the dialectics of logico-mathematical knowledge}

\begin{abstract}
The aim of the article is an analysis of the early works of Jarosław Eadosz, a Polish philosopher and mathematician, who in the 1960s conducted a thorough examination of the most important scientific accomplishments in the field of logic and mathematics from the perspective of Marxist philosophy. Being nowadays assessed as a symbol of dogmatism and orthodoxy in Polish Marxism, Eadosz revised most of the superstitions on the relationship between mathematical logic and dialectics, which have been legitimized in official Marxist philosophy since the times of Marx and Engels, in his early works. Having rejected the claims of some Marxists for the formalization of dialectics, he presented the original concept of dialectics as a methodological tool for studying the sources of logical knowledge. Combining dialectical materialism with Jean Piaget's epistemology, he formulated an elaborate, original hypothesis of the social construction of logico-mathematical knowledge, while at the same time transcending the subject-object division assumed in Marxist dogmatic epistemology.
\end{abstract}

Keywords: Jarosław Ładosz, Marxism, dialectical materialism, epistemology, formal logic, constructivism, history of mathematics 


\section{Wstęp}

Jarosław Ładosz (1924-1997) był jednym z prominentnych reprezentantów filozofii marksistowskiej w okresie PRL. Przed wojną był działaczem młodzieżowych organizacji socjalistycznych, po jej wybuchu aktywnie działał w Gwardii Ludowej i Polskiej Partii Robotniczej, przez co czas od 1943 roku do końca wojny przesiedział w niemieckich obozach koncentracyjnych. Po wojnie z powodzeniem studiował matematykę i zrobił doktorat z filozofii u Adama Schaffa, ówcześnie naczelnego polskiego filozofa marksistowskiego. Nie zaniedbywał przy tym kariery partyjnej. Przez wiele lat zarządzał katedrami i instytutami na Uniwersytecie Wrocławskim, Uniwersytecie Śląskim i na Akademii Nauk Społecznych w Warszawie ${ }^{1}$.

Obecnie Ładosz, jak zresztą wielu innych polskich marksistów, został już niemal całkowicie zapomniany. Pojawiał się niekiedy we wspomnieniach dotyczacych marksizmu w PRL, odgrywając rolę „,zarnego charakteru”, który obstawał przy „ortodoksji”, gdy inni marksiści tworzyli „rewizjonistyczne”, czyli antropologiczne, interpretacje tej filozofii. Tak został oceniony kilkanaście lat temu chociażby przez Andrzeja Walickiego, jako „ostatni Mohikanin” ortodoksji i ,pozbawiony znaczenia wyjątek" od generalnie otwartego na nowinki intelektualne polskiego marksizmu². Przez Jana Woleńskiego został natomiast zaliczony jako typowy reprezentant „marksizmu dogmatycznego" — nurtu rzekomo zakładającego, że marksizm dysponuje wystarczającą aparatura pojęciową i narzędziami, by poradzić sobie z każdym problemem filozoficznym ${ }^{3}$. Ładosz i jego tezy pojawiają się również niekiedy w różnych niszowych opracowaniach dotyczących komunizmu i marksizmu jako przykład „typowo marksistowskiego” poglądu na daną sprawę.

Wydaje się, że tego typu oceny opierają się na pracach i myśli społecznej Ładosza głównie z późnych lat sześćdziesiątych oraz lat siedemdziesiątych i osiemdziesiątych, w których rzeczywiście dowodził samowystarczalności intelektualnej „marksizmu-leninizmu” i w duchu filozofii Louisa Althussera krytykował na przykład marksistowski humanizm za faktyczną niezgodność z myślą Marksa. Niemal nikt nie pamięta ${ }^{4}$ jednak o jego wcześniejszym, ,scjentystycznym” okresie działalności intelektualnej (lata pięćdziesiąte i sześćdziesiąte), kiedy prowadził twórcze i oryginalne badania na polu filozofii matematyki i logiki w perspektywie materializmu dialektycznego. Wbrew pejoratywnemu wizerunkowi Ładosza jako dogmatycznego, czyli w domyśle mało interesującego marksisty, moim zdaniem wczesny etap jego twórczości z perspektywy historii filozofii zasługuje współcześnie na uwagę z co najmniej z trzech powodów.

\footnotetext{
1 Informacje te podaje za wspomnieniami profesora Wiesława Mysłka o Ładoszu, https://web.archive. org/web/20100416063357/http://www.smp.republika.pl:80/polemiki/Ladosz.htm (dostęp: 23.08.2020).

2 A. Walicki, Marksistowska filozofia w PRL w świetle osobistych wspomnień, „Przegląd Filozoficzny" 63 [3] (2007), s. 247-276, tu: s. 267.

3 J. Woleński, From Controlled Liberalism to Real Pluralism. The Development of Philosophy in Poland at the End of the Communism Era, [w:] 20 Years After the Collapse of Communism, N. Hayoz, D. Koleva, D. Jesien (red.), Bern 2011, s. 567.

4 We współczesnej literaturze można trafić na kilka pozytywnych odniesień do pracy Ładosza w artykule Daniela Cholewy, Trzy argumenty przeciwko konstruktywizmowi matematycznemu, ,Filozofia Nauki" 72 [4] (2010), s. 77-95.
} 
Po pierwsze, dzieła te dostarczają twórczego i pogłębionego rozwiązana problemu relacji między szeroko pojętą dialektyką (materializmem dialektycznym, logiką dialektyczną) a logiką formalną, zwłaszcza w odniesieniu do prawa niesprzeczności i prawa wyłączonego środka, oraz źródeł i ewolucji wiedzy matematycznej. Są to rozwiązania oryginalne na tle całej historii tak zwanego wschodniego marksizmu, a może i marksizmu w ogóle. Ładosz poszukiwał bowiem konkretnej odpowiedzi wobec arbitralnych i ideologicznych stanowisk dotyczacych statusu praw logiki i natury matematyki w marksizmie. Odrzucał zarówno pogląd o wyższości logiki dialektycznej i sprzeciwiał się próbom jej formalizacji, jak i krytycznie oceniał późniejsze próby przełożenia prawideł dialektyki na język logiki formalnej. Analogicznie odrzucał czysto deklaratywne wypowiedzi o „materialności” wiedzy matematycznej w dogmatycznym marksizmie, jak również trafnie krytykował próby przeszczepienia na grunt marksizmu stanowisk konstruktywistycznych.

Po drugie, w powiązaniu z pierwszym, tezy Ładosza stanowią przykład krytycznej recepcji osiągnięć zachodniej logiki i filozofii matematyki na gruncie polskiej kultury filozoficznej, gdzie po krótkim etapie stalinowskim polscy marksiści będący pod wpływem Szkoły Lwowsko-Warszawskiej przeważnie przyjmowali je dość entuzjastycznie.

Po trzecie filozofia, czy konkretnie mówiąc - epistemologia logiki i matematyki w ujęciu wrocławskiego marksisty są również ciekawym przykładem dialogu i konfrontacji ze wspomnianą polską tradycją badań nad logiką, zwłaszcza w obszarze logik wielowartościowych i logiki matematycznej. W tym sensie twierdzenia Ładosza, które chciałbym omówić, mogą być godne uwagi współczesnego pokolenia badaczy zainteresowanych marksizmem i związkami dialektyki z logiką i matematyką.

\section{Logika i matematyka pod dyktatem diamatu i późniejsze próby rewizji}

Na stosunek do logiki i matematyki w polskiej i radzieckiej filozofii marksistowskiej przez długi okres kładła się cieniem oficjalna kodyfikacja głównych praw i zasad marksizmu sformułowana pod dyktando Józefa Stalina w latach trzydziestych. Do połowy lat pięćdziesiątych oznaczało to instytucjonalnie wymuszoną konieczność podporządkowania się skodyfikowanym dogmatom powstałego w ten sposób „materializmu dialektycznego” i ,materializmu historycznego”.

Matematyka i logika nie mogły mieć w radzieckim dogmatyzmie neutralnego statusu. Podlegały pod materializm dialektyczny i jego prawa, tak jak każda inna dziedzina nauki czy rzeczywistości w ogóle. W stalinowskim ujęciu materializm dialektyczny był systemem totalnym. Był ontologią czy może raczej uniwersalistyczną metafizyką, która ze swoimi systemowymi prawidłowościami była tak zaawansowana, że w swej treści niemal nieodróżnialna od magii. Stalin twierdził bowiem, że prawa przyrody (badane przez diamat) de facto stosują się do rze- 
czywistości społecznej ${ }^{5}$. Oznaczało to teleologiczny schemat, z którego pokrótce wynika, iż dialektyczne prawa rządzących rozwojem Wszechświata od jego zarania stanowią zarazem przyczynę konieczności objęcia władzy i wprowadzenia dyktatury proletariatu ${ }^{6}$. Czarodziejski urok stalinowskiego dia matu brał się również stąd, iż kosmologiczne prawa rzekomo kształtujące historię społeczną oparte były głównie na lapidarnych, uproszczonych na potrzeby popularyzacji, dość metaforycznych wypowiedziach Marksa i Engelsa, a zwłaszcza tego drugiego. Stąd też wziął się w marksizmie pogląd o istnieniu logiki dialektycznej, będącej wyższą formą logiki zajmującej się ruchem w stosunku do „statycznej”, klasycznej logiki formalnej. Sugerował to sam Engels, choć raczej nie miał na celu odrzucenia podstawowych praw logiki, tylko polemizował z ówczesnym mechanicyzmem w przyrodoznawstwie (za eleatami traktując ruch jako sprzeczność) bądź krytykował absolutyzm moralny i istnienia wiecznych prawd, które miały być oparte na „starometafizycznym” pojmowaniu prawidłowości logicznych ${ }^{7}$. Poglądy klasyków marksizmu zostały zradykalizowane przez właściwego prekursora stalinowskiego podziału na diamat i histmat, czyli Plechanowa, który dowodził wprost, że w obliczu osiągnięć dialektyki logika formalna i jej prawa stały się przestarzałe ${ }^{8}$. Zbliżone tezy wygłaszał Lenin, choć jego prace, podobnie jak klasyków, miały polemiczny i interwencyjny, a nie programowy charakter. Tego typu poglądy w różnej formie wyrażała jednak większość marksistów w epoce stalinowskiej.

Stanowisko materializmu dialektycznego wobec problematyki matematycznej było jeszcze bardziej ogólnikowe. Radzieccy matematycy początkowo dialektyką w ogóle się nie interesowali, a następnie pod wpływem stalinizacji powtarzali tezy Engelsa, który sądził, że matematyka wyższa (zwłaszcza rachunek różniczkowy) ma charakter dialektyczny, ponieważ dochodziło w jej ramach do paradoksów z punktu widzenia matematyki elementarnej, a różniczkowanie miało przypominać prawo negacji negacji ${ }^{9}$. Pewną zmianę przyniosło opublikowanie w 1933 roku Marksowskich Rękopisów matematycznych. Wówczas zaczęto powoływać się na tę pracę jako dowód społecznego charakteru wiedzy matematycznej, choć i te stwierdzenia miały dość ogólny charakter. Sformułowano jednak ogólne założenia dialektyczno-materialistycznej teorii matematyki. Po pierwsze, każdy aksjomat matematyki miał mieć swoje źródło empiryczne i w ten sposób wywodzić się z realnego świata. Po drugie, wszystkie zachodnie orientacje - logicystyczna, formalistyczna, intuicjonistyczna - miały reprezentować filozofię idealistyczną. Po trzecie, podkreślano praktyczne zastosowania matematyki w nauce i inżynierii. Powoływanie

5 J. Stalin, O materializmie dialektycznym i historycznym, [w:] idem, Zagadnienia leninizmu, Warszawa 1949, s. 536.

6 Ibidem, s. 540-541 n.

7 F. Engels, Anty-Dühring, Warszawa 1948, s. 118-115, 142-143; idem, Dialektyka przyrody, Warszawa 1953, s. 223-227.

8 J. Plechanow, Podstawowe zagadnienia marksizmu, Warszawa 1949, s. 109, za: W. Luty, Sprzeczności logiczne a dialektyczne, http://smp.edu.pl/sprzecznosci-logiczne-a-sprzecznosci-dialektyczne/\#sdfootnote5sym (dostęp: 25.08.2020).

9 F. Engels, Anty-Dühring, s. 159-163. 
się na owe trzy dogmaty miało zapewniać matematykom spokojną pracę w ramach radzieckiego systemu politycznego ${ }^{10}$.

Pomimo takich obostrzeń zarówno radzieccy, jak i polscy marksiści z zainteresowaniem spoglądali na odkrycia w fizyce (dowodzące sprzeczności wersji kwantowej z fizyczną) oraz dokonania w obszarze logiki matematycznej, między innymi Russela (wykrycie antynomii w teorii mnogości) i Gödla (niemożliwość przeprowadzenia dowodu niesprzeczności w zbiorach zawierających arytmetykę liczb naturalnych, które odrodziły spory o zasadność zasady sprzeczności) ${ }^{11}$. Marksiści doszukiwali się w tym potwierdzenia własnego spojrzenia na sprzeczności.

W pierwszych latach po wojnie w Polsce sporym zainteresowaniem cieszyła się z podobnych względów logika wielowartościowa, którą stworzył Jan Łukasiewicz, począwszy od jego słynnej pracy $O$ zasadzie sprzeczności u Arystotelesa ${ }^{12}$. Eukasiewicz sądził, że rozwiąże wykryty przez siebie problem istnienia przedmiotów sprzecznych, tworząc systemy logik trój- i nieskończenie wartościowych, zakładając, że stanowią one rozwinięcie logiki modalnej obecnej już u Arystotelesa ${ }^{13}$. Jego odkrycia i inne modele logik wielowartościowych spotkały się z zainteresowaniem polskich marksistów po wojnie.

Stanowisko Plechanowa w swoich pracach z lat czterdziestych utrzymywał Schaff, powołując się właśnie na osiągnięcia polskich logików, i postulował stworzenie sformalizowanej „logiki sprzeczności” odpowiadającej dialektyce ${ }^{14}$. Twierdził, że logika formalna „odzwierciedla prawa statycznej rzeczywistości”, a dialektyka jest logiką „ruchu” ${ }^{\prime 15}$. Nie zrobił jednak nic w kierunku stworzenia takiej logiki. Ogólnikowość i metaforyczność tego typu wywodów została wychwycona w pracach katolickiego księdza Kłósaka ${ }^{16}$ oraz neopozytywisty Łubnickiego, chociaż ten również zauważył zbieżność rozumienia niesprzeczności w marksizmie z zasadami logik wielowartościowych ${ }^{17}$.

Już kilka lat później w polskiej myśli marksistowskiej dokonał się zwrot za sprawą wywodów Kazimierza Ajdukiewicza, do których znowuż entuzjastycznie odniósł się ten sam Schaff. Wybitny polski filozof i logik w swoim artykule Zmiana i sprzeczność $(1948)^{18}$ rozwiązał starożytne aporie eleatów, udowadniając, że da się w języku logiki formalnej opisać ruch i zmianę, jednocześnie potwierdzając zasadność praw dialektyki w pewnym zakresie. Jego argumentacja głosiła, że przejście

10 A. Vucinich, Soviet Mathematics and Dialectics in the Stalin Era, „Historia Mathematica” 27 (2000), s. 65 .

11 W. Luty, op. cit.

12 Zob. J. Łukasiewicz, O zasadzie sprzeczności u Arystotelesa, Warszawa 1987.

13 J. Łukasiewicz, Sylogistyka Arystotelesa z punktu widzenia współczesnej logiki formalnej, tłum.

A. Chmielewski, Warszawa 1988, s. 212-243.

14 Ibidem.

15 A. Schaff, Wstęp do teorii marksizmu, Warszawa 1947, s. 147-148.

16 Zob. T. Gadacz, Krytyka materializmu dialektycznego w pracach Kazimierza Kłósaka, „Znak” 350 (1984), s. 33-46.

17 N. Eubnicki, Teoria poznania materializmu dialektycznego, „Annales Universitatis Mariae CurieSkłodowska Lublin Polonia Sectio F" 1-2 (1946) s. 137.

18 Zob. K. Ajdukiewicz, Zmiana i sprzeczność, [w:] idem, Język i poznanie, t. 2, Warszawa 1965, s. $90-106$. 
ze stanu A do stanu B nie zakłada żadnego stanu pośredniego, więc nie narusza prawa wyłączonego środka, pod warunkiem że podkreślimy, iż stan $\mathrm{B}=$ nie $\mathrm{A}$, a „nie A” zawiera każdy stan inny od A. W 1955 roku Schaff mniej więcej powtórzył argumentację Ajdukiewicza, podkreślając, że stanowisko klasyków marksizmu powołujących się na eleatów było ich subiektywnym błędem ${ }^{19}$. Stanowisko to zostało później przejęte przez gros marksistów o orientacji scjentystycznej.

Poststalinowska odwilż rozbudziła też w ZSRR i PRL nowoczesne badania matematyczne i ich aplikacje do nowych gałęzi wiedzy, takich jak cybernetyka. Sporym zainteresowaniem zaczęła cieszyć się idea intuicjonizmu w matematyce, głównie w wydaniu Brouwera i Weila. Brouwer zakładał, że wiedza matematyczna nie jest związana z językiem matematyki — pojęcie liczb naturalnych zostaje wytworzone w umyśle danej jednostki, a dalsze są w tym umyśle „konstruowane”, sam język matematyki jest tylko środkiem wymiany idei między naukowcami ${ }^{20}$. W ten sposób wiedza matematyczna miałaby mieć charakter kantowskich sacdów syntetycznych apriori $^{21}$. W ZSRR na gruncie tego typu intuicjonizmu A.A. Markow i N.A. Szanin stworzyli podwaliny radzieckiej tradycji konstruktywistycznej. Zakładali, że cała wiedza matematyczna ma charakter konstrukcyjny, a matematyka zajmuje się rozważaniem wyników działań realizujących te konstrukcje. Wszystkie operacje matematyczne miały zaczynać się od jasnej identyfikacji intuicyjnie wybranych klas obiektów (grafy, macierze itd.). Radzieccy konstruktywiści koncentrowali się na analizie rekurencyjnej procesów konstrukcyjnych, opierając się na algorytmach traktowanych jako pomost między konstrukcjami teoretycznymi a konkretnymi przedmiotami badań. Podkreślali też społeczno-kulturowy charakter źródeł wiedzy matematycznej, lecz nie potwierdzali tego konkretnymi badaniami empirycznymi ${ }^{22}$. W Polsce za umiarkowanego konstruktywistę uchodził Mostowski, który dostrzegał słabości tej teorii, ale uważał ją za godną akceptacji ze względów pragmatycznych, gdyż jej stosowanie miało przynosić wymierne efekty naukowe ${ }^{23}$.

Recepcja rozwoju wiedzy logikomatematycznej była więc na ogół w marksizmie dość ogólnikowa i słabo argumentowana, a jej związek z tezami materializmu dialektycznego oparty raczej na dobrej wierze niż pogłębionych badaniach. Ładosz dobrze zdawał sobie z tego sprawę i jego stanowisko zakładało eliminację tych słabości poprzez merytoryczną krytykę nowych trendów w logice i matematyce.

\section{Krytyka logik wielowartościowych}

Trzeba zaznaczyć, że Ładosz jako wykształcony matematyk, w przeciwieństwie do typowych stalinowskich ideologów, odznaczał się wysoką kulturą myślenia lo-

19 J. Ładosz, Wielowartościowe rachunki zdań a rozwój logiki, Warszawa 1961, s. 255-256.

20 Za: https://plato.stanford.edu/entries/intuitionism/\#Bro (dostęp: 25.08.2020).

21 J. Ładosz, Szkice z epistemologii matematyki. Matematyka jako działalność konstruktywna, Warszawa 1968, s. 36 .

22 A. Vucinich, Soviet Mathematics and Dialectics in the Post-Stalin Era: New Horizons, „Historia Mathematica" 29 (2002), s. 13-39.

23 J. Ładosz, Szkice z epistemologii matematyki, s. 67. 
gicznego. Szczególną estymą darzył Arystotelesa. Uznawał klasyczny rachunek zdań za naukowe potwierdzenie praw wykrytych przez niego w starożytności ${ }^{24}$. Sądził, że to właśnie Stagiryta jako pierwszy pojmował kategorie modalne w sposób dialektyczno-materialistyczny (traktując je jak Engels jako dotyczące obiektywnie istniejącego świata ${ }^{25}$ ), ale niestety usiłował włączyć je w sztywny, jednolity system logiki modalnej, co zostało wykorzystane przez średniowiecznych scholastyków, którzy system ten rozwinęli, jednocześnie oczyszczając go z materializmu ${ }^{26}$.

W tym też tkwi ideowe źródło niezgody Ładosza z Łukasiewiczem. Ładosz krytycznie podkreślał, iż słynny polski logik kontynuował idee Brentana i Twardowskiego, które wskrzesiły scholastyczną metodę ujmowania problemów filozoficznych jako formalno-logicznych ${ }^{27}$, kontynuując tym samym tradycję wypaczania ,prawdziwej" myśli Stagiryty. Ładosz doceniał wkład dzieła Łukasiewicza o zasadzie sprzeczności, uznając to za prezentację najnowszych osiągnięć logiki matematycznej. Podkreślał jednak, że zawiera „scholastyczne” źródło, jakim była Meinonga koncepcja przedmiotów sprzecznych (kwadratowe koło itp.), która była łączona z antynomiami teorii mnogości (istnienie sprzecznych przedmiotów w matematyce) ${ }^{28}$. Innym nie do końca uzasadnionym założeniem Łukasiewicza miało być traktowanie indukcji jako inwersji dedukcji — „dobieranie nieznanych racji do znanych następstw”, co miało przeczyć praktyce przyrodoznawstwa ${ }^{29}$.

Jak wiadomo, Łukasiewicz wyróżnił trzy sformułowania zasady sprzeczności: ontologiczną — żaden przedmiot nie może zarazem posiadać i nie posiadać tej samej cechy; logiczną — nie mogą być prawdziwe dwa sądy przyznające sprzeczne cechy temu samemu przedmiotowi; psychologiczną — w jednostkowym umyśle nie moga jednocześnie istnieć dwa sprzeczne sądy ${ }^{30}$. O ile Szkoła Warszawska odrzuciła ostatecznie metafizykę brentanowską, popularny pozostał pogląd o tożsamości logiki i ontologii. Kierując się tą dyrektywą, Łukasiewicz utożsamił ontologiczne i logiczne rozumienie zasady sprzeczności ${ }^{31}$. Natomiast po zbudowaniu logiki czterowartościowej w kontrze do Stagiryty odrzucił empiryczną poznawalność praw logiki ${ }^{32}$. Połączenie logiki z ontologią doprowadziło go do wniosku, że logika dwuwartościowa ma charakter deterministyczny w ontologicznym sensie ${ }^{33}$ — skoro wszystko musi być „prawdziwe” albo „fałszywe”, zatem to, co prawdziwe, musi być konieczne - wynika to zresztą z zasady niesprzeczności. Trójwartościowa logika, dodając do rachunku możliwość, miała implikować w analogiczny sposób indeterminizm.

\footnotetext{
24 J. Ładosz, Wielowartościowe rachunki zdań a rozwój logiki, s. 19.

25 Ibidem, s. $112-117$.

26 Ibidem, s. 106.

27 Ibidem, s. 41.

28 Ibidem, s. 42.

29 Ibidem, s. 44.

30 J. Łukasiewicz, O zasadzie sprzeczności u Arystotelesa, Warszawa 1987, s. 10-13.

31 W. Luty, Sprzeczności logiczne a dialektyczne...

32 J. Ładosz, Wielowartościowe rachunki zdań a rozwój logiki, s. 63.

33 Ibidem, s. 58.
} 
Krytyczną analizę logiki trójwartościowej Ładosz uważał za istotną ze względów praktycznych. Inspirowała bowiem tworzenie nowych logik modalnych (Lewis, Carnap, Reichenbach i inni), intuicjonizmu (Brouwer) oraz wpływała na marksistów (promował ją Suszko), a przede wszystkim miała zacząć odgrywać znacząca rolę $\mathrm{w}$ rozwoju techniki ${ }^{34}$. Innymi słowy osiągnięcia w logice matematycznej oddziaływały zarówno na problematykę budowy socjalizmu, czyli słynną marksistowską b a zę, jak i metodologicznie na samą teorię marksizmu. Stąd też pozornie niewinna ewolucja logiki matematycznej nieuchronnie miała prowadzić do nowej wersji starej, dziewiętnastowiecznej batalii materializmu z idealizmem. Zdaniem Ładosza afirmacja logik wielowartościowych sprowadzała się do uznania tradycyjnej logiki formalnej za niezdolną do: a ) ujęcia wielu dedukcyjnych prawidłowości; b) rozwiązania problematyki sądów modalnych i ich logiki; c) podtrzymania prawa niesprzeczności ${ }^{35}$.

Sednem krytyki Ładosza jest odrzucenie pretensji praw logiki modalnej do uniwersalności i oczywistości przy jednoczesnej obronie logiki tradycyjnej. Miało to wynikać z ogólnego filozoficznego problemu logik wielowartościowych, jak i całego pozytywizmu logicznego - był w nim idealizm metodologiczny ${ }^{36}$. Jego źródłem miały być wspomniane już scholastyczne wpływy, co oznaczało konkretnie wyrugowanie z praw modalnych kategorii rzeczywistości $\rightarrow$ aktualnego kształtu świata, czyli tego, co istnieje; przy powiązaniu pozostałych: konieczności, możliwości i przypadku ${ }^{37}$. Według autora ,samodzielna jej rola sprowadzona została do sądów jednostkowych o podmiocie w supozycji formalnej”38. W filozoficznej interpretacji oznacza to, że rzeczywistość zastąpiono jej abstrakcją, zakładająca, iż jest ona „pozaczasowym zbiorem faktów jednostkowych czy rzeczy”. Pozostałe kategorie, historycznie rzecz biorąc, zawsze były wieloznaczne oraz mogą mieć różny zakres w zależności, czy tyczą się sądów ogólnych, czy jednostkowych. Odrzucenie związku kategorii modalnych ze światem zmysłowym oznaczało jednak utożsamienie ich z pojęciami ogólnymi jak w średniowiecznej scholastyce. Co więcej, logika trójwartościowa, uniwersalizując prawa modalne, gubi też wedłig Ładosza kategorię możliwości, utożsamiając ją z przypadkiem.

Według autora Materializmu dialektycznego w logice wielowartościowej w spójniku jest zostało połączone znaczenie atrybutywne (stosunek jednostkowego do ogólnego) i egzystencjalne. Ale jedność atrybutywnego i egzystencjalnego znaczenia jest zachodzi zdaniem Ładosza tylko w rzeczywistości zmysłowej. Ulegają one rozdzieleniu wraz z wyróżnieniem w poznaniu tego, co ogólne. To abstrakcyjne rozdwojenie jest konieczne do prowadzenia działalności naukowej. A zarazem każdy sąd prawdziwy orzeka o rzeczywistości. Dzieje się tak dzięki kategoriom modalnym, które pośredniczą między tym, co ogólne, a jednostkowe, ale utożsamienie obu aspektów prowadzi do fantazji (istnienie gazu doskonałego obok rzeczywistych). Prowadzi to też do nominalizmu i uznania egzystencjalnego jest tylko dla

\footnotetext{
34 Ibidem, s. 65-97.

35 Ibidem, s. 98-101.

36 J. Ładosz, Materializm dialektyczny, Bydgoszcz 1973, s. 40.

37 J. Ładosz, Wielowartościowe rachunki zdań a rozwój logiki, s. 108.

38 Ibidem, s. 114.
} 
sądów jednostkowych. Implikuje to jednak negację obiektywnego i materialnego charakteru kategorii modalnych. Zostają więc przeniesione do relacji między zdaniami. Rzeczywistość i konieczność zostają w ten sposób w logice wielowartościowej relegowane do pozaczasowej sfery prawdy i fałszu ${ }^{39}$.

Wobec tego modalności ujęte jako pojęcia formalno-logiczne są mylone z pojęciami konieczności i możliwości występującymi w „realnym” świecie przyrodniczym i społecznym, ponieważ logika formalna nie może abstrahować od egzystencjalnej funkcji jest. Ich obiektywność jest sztuczna, bo istnienie tylko w świecie logiki może być tylko istnieniem idealnym, zależnym od umysłu ${ }^{40}$. Żadna więc logika nie może mieć uniwersalnego charakteru, bo uogólnia tylko część prawidłowości obiektywnie istniejących w świecie ${ }^{41}$. Dlatego też logika zawsze napotyka na ogromne kłopoty podczas przełomowych odkryć naukowych, jak odkrycie mikroświata kwantowego. Próbuje wtedy tworzyć nowe uogólnienia - w tamtym wypadku pod postacią „logiki kwantowej”. Wszelkie takie próby skazane są na niepowodzenie ze względu na historyczność danego etapu poznania - nie każda realna konieczność jest tożsama z koniecznością formalno-logiczną, wręcz przeciwnie. Przykładowo formalno-logiczne pojęcie konieczności klasycznej elektrotermodynamiki okazało się sprzeczne z pojęciem konieczności w świecie kwantowym ${ }^{42}$.

Końcowa ocena Ładosza konkluduje, że logiki modalne rozwiązują część problemów wcześniejszych systemów filozoficznych, ale nie oznaczają rewolucji w stosunku do klasycznej logiki arystotelejskiej, wręcz cofają się, abstrahując od czasowości i zmysłowości, nawet jeżeli są to tylko założenia metodologiczne. Wyjątkiem, zdaniem polskiego marksisty, jest tu Carnap, który unowocześnił logikę względem potrzeb matematyki, kosztem jej zakresu ${ }^{43}$.

\section{Krytyka konstruktywizmu}

Ładosz dostrzegał mocne strony konstruktywizmu. Choć leżący u jego podstaw intuicjonizm miał być tylko „subiektywną, ahistoryczną operacją umysłową”, to zawdzięczamy mu postępy w badaniu matematycznej indukcji ${ }^{44}$. Badając efektywność matematycznych pojęć i dowodów, konstruktywizm traktuje matematykę jako coś pozostającego w ruchu, ujmuje ją (za Quinem) „w terminach postępującego tworzenia" ${ }^{45}$. Ponieważ u podstaw intuicjonizmu i konstruktywizmu leżą badania z zakresu logik wielowartościowych, także tutaj mamy do czynienia z negacją kolejnej zasady klasycznej logiki — wyłączonego środka. Wedle konstruktywistów w zbiorach rekurencyjnie przeliczalnych nie sposób rozstrzygnąć kwestii przynależności do zbioru każdej liczby naturalnej ${ }^{46}$. Wynika to z problemu nieskończono-

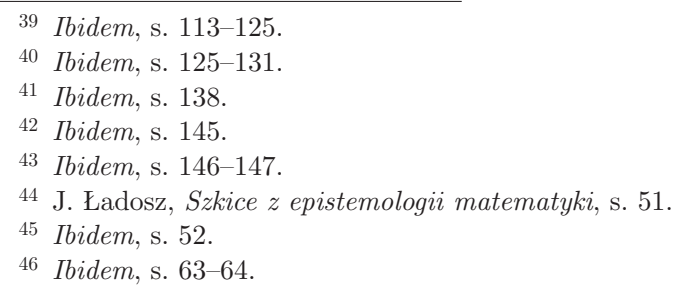


ści, ponieważ dla efektywnego rozstrzygnięcia kwestii odpowiedniej przynależności każdej liczby naturalnej należałoby wykonać nieskończenie wiele kroków. Oprócz tego próby uzupełnienia zbiorów mogą prowadzić do zbiorów znajdujących się zupełnie gdzie indziej w hierarchii matematycznej. Nie da się więc uzupełnić zbiorów rekurencyjnych w skończonej liczbie operacji. Ostatecznie konstruktywista

postulując ograniczenie matematyki do z góry określonej klasy zbiorów konstruktywnych, nie może [...] zaakceptować powszechnej ważności tej zasady, ponieważ popadłby wówczas w kolizję z wymienionym postulatem. Operację uznania i tertium non datur uzna on za uprawnione wyłącznie w odniesieniu do tych wypadków, w których nie wyprowadzają one poza zbiory budowane za pomocą uznanych przez niego granic konstrukcji ${ }^{47}$.

Ładosz postrzegał konstruktywizm jako jedność różnorodnych nurtów. Nie zgadzał się z Mostowskim i Heytingiem, że należy oddzielić filozofie konstruktywizmu od tego, co konstruktywne w matematyce. Wielu matematyków zajmujących się konstrukcjami nie odżegnuje się bowiem wcale od ich filozoficznych konsekwencji ${ }^{48}$. W związku z tym proponował zdefiniować go jako epistemologię podstaw matematyki: „, których miejsce dominujące zajmuje tendencja sprowadzania całej matematyki do konstrukcji i uznawania, że prawa obywatelstwa w tej nauce posiadaja tylko te pojęcia, które mogą być konstruowane"49. Krytyczny stosunek Ładosza do konstruktywizmu wiązał się z idealistycznym założeniem nurtów wchodzących w jego skład, czyli że wszelkie twory matematyczne są konstruktem ludzkiego umysłu, oraz konstruktywistycznymi próbami przekroczenia granic klasycznej logiki formalnej.

W świetle wywodów autora Szkiców z epistemologii matematyki można wyróżnić cztery powiązane wzajemnie filozoficzne ułomności konstruktywizmu: 1) formalizm, 2) spekulatywizm, 3) subiektywizm, 4) antyhistoryzm.

1. Zarzut pod adresem formalizmu ma podobną naturę jak obiekcje względem logiki wielowartościowej. Prowadzi bowiem do zerwania z obiektywnymi prawidłowościami obiektywnie istniejącego świata. Próby formalnej klasyfikacji konstruktywizmu jako wersji nominalizmu niewiele w tej kwestii wyjaśniały, bo więcej mówiło to o metaklasyfikacjach danych filozofów niż o naturze obiektów konstrukcyjnych. Na przykład według Quine'a nominalistyczne ujęcie obiektów matematycznych traktuje je jak pojęcia ogólne, ale już według Betha — jako konkretne byty ${ }^{50}$. Generalnie stanowiska nominalistyczne o naturze obiektów matematycznych i ich związkach ze światem materialnym nie mówią nic więcej ponadto, co głoszą sami intuicjoniści i konstruktywiści. Zatem bez względu na klasyfikację w sporze o powszechniki i próby ujmowania obiektów matematycznych jako pustych „schematów”, „grafów” czy „znaków”, nie dowiadujemy się niczego konkretnego o naturze konstrukcji matematycznych.

2. Ze względu na uporczywy formalizm próby wyjaśnienia wiedzy matematycznej miały charakter czysto spekulatywny. Jeszcze w latach trzydziestych radziecki

\footnotetext{
47 Ibidem, s. 64.

48 Ibidem, s. 67.

49 Ibidem, s. 68.

50 Ibidem, s. $75-82$.
} 
matematyk Gliwienko twierdził, że matematyka prowadzi działania na istniejących materialnie poza umysłem znakach. Podobnie Bridgman uznawał, że niektóre operacje matematyczne wywodzą się z rzeczywistych operacji fizycznych. Jednak w obu przypadkach były to tylko puste deklaracje, niepoparte dowodami ${ }^{51}$. Ładosz opisuje jeszcze szereg innych definicji, ale każda ma charakter arbitralny i nie potwierdza empiryczności matematyki. Nawet fizjologiczna interpretacja Myhilla, który traktował centralny system nerwowy jako tożsamy z maszyną Turinga, odrzucającą niekonstruktywne operacje jako bezsensowne, nie ma żadnego potwierdzenia, gdyż sam autor odrzucał próbę zbadania tego, uznając to za psycho$\operatorname{logizm}^{52}$. Choć empirycznych teorii matematyki nie brakuje, to wszystkie maja charakter spekulatywny, gdyż ich rzecznicy, jak Myhill, odżegnują się od praktyki i badań empirycznych ${ }^{53}$.

3. Matematycy szukają konkretnych reprezentacji swoich teoretycznych konstrukcji, ale zamiast szukać ich „w zjawiskach i procesach przyrody" szukają ich w „uformowanych strukturach pojęciowego myślenia”, przeto nie dostrzegają konieczności „ujawnienia uch historycznych mechanizmów”. Ogłoszenie przez konstruktywistów intuicji jako ostatecznej podstawy wiedzy matematycznej prowadzi nieuchronnie do subiektywizmu i konwencjonalizmu, wynikającego z relatywizmu teoriomnogościowego, który został zinterpretowany tak, że w ostateczności za wszystkim stoją prywatne intuicje matematyków ${ }^{54}$. Zatem u podstaw nowoczesnych konstrukcji matematycznych i cybernetycznych leży „przestarzałe” kantowskie przekonanie, że wiedza ścisła i pewna ma wyłącznie charakter podmiotowy i że najważniejsza jest „wiedza o biegu własnych myśli”55. Subiektywność ta jej sprzeczna z obiektywnymi, społecznymi walorami matematyki, choć nie przeszkadza w dokonywaniu wielkich odkryć matematycznych ${ }^{56}$.

4. Odmowa prowadzenia badań empirycznych umotywowana była sporem psychologizmu z antypsychologizmem wielu filozofów matematyki. Zdaniem Ładosza rzeczywiście nie da się uzyskać satysfakcjonującej odpowiedzi na pytanie o naturę bytów matematycznych tylko w psychologii. Ale odrzucenie konkretnych badań przy obstawaniu przy formalizmie i subiektywizmie prowadzi jedynie do odrzucenia historii społecznej praktyki matematycznej, zawężając tylko pole widzenia na naturę jej obiektów. Z jednej strony poznanie pojęciowe ,stanowi społeczny wytwór ludzkich pokoleń, grup ludzi współdziałających ze sobą w przestrzeni i w czasie, treść poznania określona jest nie przez aparat psychiczny nabyty w toku biologicznej ewolucji, lecz działalność ludzkich kolektywów"57. Matematyka ma zastosowanie $\mathrm{w}$ materialnym świecie, a to dowodzi jej ziemskiego, niepsychologicznego charakteru $^{58}$. Z drugiej strony badania psychologiczne są ogólnie potrzebne, żeby

\footnotetext{
51 Ibidem, s. 73-74.

52 Ibidem, s. 104-105.

53 Ibidem, s. 132.

54 Ibidem, s. 137.

55 Ibidem, s. 136.

56 Ibidem, s. 140-143.

57 Ibidem, s. 159-160.

58 Ibidem, s. 164.
} 
wiedzieć, w jaki sposób człowiek poznaje istniejące prawa logiki i matematyki ${ }^{59}$, dlatego té antypsychologizm $=$ antyhistoryzm ${ }^{60}$. Zatem alternatywa sporu psychologizmu z antypsychologizmem jest „badanie historycznego procesu powstania i rozwoju matematycznej wiedzy w przyczynowej zależności od materialnego działalności społecznej ludzi, która zespala ludzi z przyrodą"61.

\section{Logika dialektyczna jako źródło wyjaśnienia i przezwyciężenia sprzeczności logicznych}

W przeciwieństwie do Łukasiewicza i innych Ładosz sprzeciwiał się traktowaniu logiki i matematyki tylko jako narzędzi, których status filozoficzny jest jedynie kwestią konwencji. Według niego logika to

nauka badająca powszechne właściwości osiągania prawdy w myśleniu pojęciowym. Stanowi integralną i centralną część ogólnej teorii i metodologii poznania. Logika dialektyczna bada specyfikę przejawiania się praw dialektycznych występujących w ruchu form i myśli ludzkiej, osiągającej „prawdziwe” poznanie, Logika matematyczna bada ,ilościowe strony prawidłowości logicznych”62.

I ,jako całość nie może zawierać silniejszych związków niż już odkryte w matematyce" ${ }^{63}$, rachunki zdań zaś są ,niczym innym jak zastosowaniem praw algebry do praw logiki" 64 . Logika wielowartościowa ma bogate zastosowanie w matematyce, ale implikuje poważne problemy filozoficzne. Neopozytywiści i inni „burżuazyjni filozofowie" utożsamiali prawdę z rozstrzygalnością, z dowodliwością istnienia, z definiowalnością, oddzielając prawdę od istnienia ${ }^{65}$.

Projekt logiki dialektycznej Ładosza jest też odpowiedzią na próby sformalizowania praw dialektyki w ramach logiki wielowartościowej, co z omówionych już przyczyn miało być nie do pogodzenia z materializmem. W ujęciu polskiego marksisty logika dialektyczna nie postuluje formalnego wnioskowania z sądów logicznie sprzecznych, nie poprawia wykrytych przez logikę formalną obiektywnych form myślenia. Uznawanie niektórych sądów sprzecznych nie jest samo w sobie błędem, choć sygnalizuje, że zawarta w nich ,prawda” ma charakter względny i występuje tam element „fałszu”, jednak niedozwolone jest we wnioskowaniu naruszenie zasady niesprzeczności. Nie można przeczyć prawom logiki formalnej. Marksistowska „logika sprzeczności” jest więc panlogizmem mającym swe źródło w heglowskim idealizmie $^{66}$. Zdaniem Ładosza Plechanow i Schaff traktowali dialektykę i logikę jako odbicie „praw” dialektyki przyrody i myślowe odbicie jej „ontologii”, zaniedbując epistemologię - nie odpowiadają tym samym na słuszne pytanie, jak w prak-

\footnotetext{
59 Ibidem, s. 163.

60 Ibidem, s. 179.

61 Ibidem, s. 167.

62 J. Ładosz, Szkice z epistemologii matematyki, s. 368.

63 Ibidem, s. 353.

64 Ibidem, s. 310.

65 Ibidem, s. 345.

66 Ibidem, s. 279.
} 
tyce stosować owa „logikę dialektyczną"67. Przejęte później przez Schaffa wyjaśnienie Ajdukiewicza zdaniem Ładosza jest abstrakcyjnie poprawne, ale nie wiadomo, co jest „tajemnym” źródłem przejścia ze stanu A do stanu B. Na przykład atom uranu u238 przechodzi ze stanu A do nie-A. Da się to opisać językiem logiki formalnej. Przyczyną zmiany są jednak jego neutrony i protony, co wywołuje logiczną sprzeczność z zasadami elektrodynamiki. Stan A okazuje się tylko fluktuacja zmiennych sił68.

Jak trafnie zauważył Ładosz, typowe w marksizmie tłumaczenie sprzeczności dialektycznej jako „jedności przeciwieństw” to metafora, która niewiele wyjaśnia. Logiczną sprzeczność definiował więc następująco:

własność przysługująca określonym myślom ludzkim takim, z których — zgodnie z prawami logiki formalnej — inferować można dwa sądy przeczące sobie nawzajem. Logiczna sprzeczność może występować w myśli jednego człowieka, między myślami (poglądami) różnych ludzi, między rozmaitymi teoriami naukowymi itp. [...] Logiczne sprzeczności, w szczególności logiczne pojęcia, istnieją w myśli niezależnie od tego, czyśmy sobie tę ich własność — sprzeczność — uświadomili, czy nie ${ }^{69}$.

„Sprzeczność logiczna, na którą napotyka poznanie w swoim rozwoju”, która nie wynika z błędów logicznych popełnionych w trakcie procesu myślowego, jest sprzecznością dwóch sądów, uwarunkowaną przez „dialektyczną sprzeczność poznawanego obiektywnie zjawiska, procesu, przedmiotu rzeczywistości", nie jest więc tylko subiektywna ${ }^{70}$. Do prawdy w zgodzie z tym można dojść tylko poprzez rozwiązanie tego typu sprzeczności, a nie ich sankcjonowanie, jak robi to logika wielowartościowa, odrzucając zasadę sprzeczności. Należy zbadać sprzeczność dialektyczną danego przedmiotu, żeby usunąć sprzeczność logiczną: „odkrycie logicznej sprzeczności w myśli - to pierwszy etap odkrycia dialektycznej sprzeczności samego przedmiotu myśli"71. Przykładami wykrywania i przezwyciężania takich sprzeczności były według Ładosza teoria ekonomiczna Marksa, rozwiązująca antynomie klasycznej ekonomii, oraz uznanie sprzeczności między mechaniką klasyczna a kwantową przy próbach ich przezwyciężania.

Logiczna sprzeczność stanowi zarazem dialektyczną sprzeczność poznania. Do sprzeczności logicznych stosuje się odkryte przez dialektykę prawa, w tym jedność przeciwieństw - same sprzeczności logiczne są względne i czasowe, ulegają eliminacji w trakcie rozwoju wiedzy; walka przeciwieństw (oczyszczenie myśli ze sprzeczności prowadzi do nowych ad infinitum) jest absolutna. Ostatecznie więc: „Prawo sprzeczności logiki dialektycznej mówi o tym, że ruch poznania pojęciowego dokonuje się poprzez rozdwajanie jedności pojęć w wyniku powstawania i rozwiązywania logicznych sprzeczności"72. Sprzeczności logiczne powstają w poznaniu, a logika dialektyczna ma przezwyciężać je w myśleniu — poprzez rozdwojenie jedności pojęcia i poznanie jego sprzecznych stron — „w oparciu o uogólnienie

\footnotetext{
67 Ibidem, s. 255.

68 Ibidem, s. 276-277.

69 Ibidem, s. 259.

70 Ibidem, s. 261.

71 Ibidem, s. 263.

72 Ibidem, s. 268.
} 
nowych danych praktyki"73. Wobec tego staje się jasne, że logika formalna żadnego ratunku w postaci przypisywania jej błędnej pełności epistemologicznej i ontologicznej nie potrzebuje ${ }^{74}$. Pracę na tym polu ma wykonywać za nią dialektyka. Ładosz zastrzega przy tym, że logika dialektyczna może negować dawne poznanie tylko wtedy, kiedy wynika z niej nowy rozwój poznawczy. Siłą rzeczy więc oznacza to ,zbadanie całej historii i aktualnego stanu zagadnienia”. Dotyczy to również jej samej $^{75}$. Ostatecznie sprzeczność (dialektyczna) ma szersze znaczenie niż w logice formalnej. Oznacza, że sprzecznością układu A jest taki proces B, który jest koniecznym warunkiem istnienia, trwania i rozwoju A, a jednocześnie jego bieg stanowi przesłankę, możliwość unicestwienia A, w określonych warunkach prowadząc do nieuchronnej jakościowej przemiany $\mathrm{A} 1^{76}$.

Spróbuję doprecyzować te wywody Ładosza. Dialektyka według niego to historyczno-genetyczna metoda badania zjawisk świata ${ }^{77}$. Logika dialektyczna w wąskim sensie to „ogólna teoria rozwoju pojęć, sądów i systemów sądów w procesie zdobywania wiedzy oraz sprzężona z tą teorią postępowaniem poznawczym", a w szerokim to logika rzeczy, logika przyrody, historii itd. ${ }^{78}$ Nie jest oddzielna dyscypliną, lecz raczej zastosowaniem metody dialektycznej do danego zjawiska ${ }^{79}$. Sprzeczności logiczne odgrywają pozytywną rolę jako detektor anomalii w danej teorii czy zespole przekonań. Metoda dialektyczna bada historię i genezę sprzeczności przedmiotu będącego źródłem sprzeczności logicznej, wskazując możliwość ich przezwyciężenia drogą negacji negacji. Uściślając koncepcję Ładosza przy pomocy terminologii wprowadzonej do filozofii nauki przez Amsterdamskiego, można podsumować, że logika dialektyczna jest id eał em poznania naukowego (zawierającym określone przekonania epistemologiczne i ontologiczne), wyznaczającym wraz z logiką formalną metodologiczne reguły badań ${ }^{80}$.

\section{Źródła wiedzy logicznej i matematycznej}

W świetle wcześniejszych rekonstrukcji dialektyka względem logiki formalnej i matematyki w szerokim sensie jest ich logiką (metodologią), ontologią i epistemologią, wywiedzioną z ich własnej genezy, historii i aktualnego stanu badań. Jej procedura badawcza stanowi

zespół zabiegów poznawczych, mających na celu o d tw o r z e n i e procesu powstawania pojęć, operacji i teorii współczesnej matematyki w jego prawidłowościach, w jego przyczynowym przebiegu i o dkrywanie na tej drodze rzeczywistego związku tych pojęć, operacji i teorii z prawidłowościami przekształceń świata materialnego, przekształceń włączanych historycznie w zakres ludzkich działań społecznych w tym świecie ${ }^{81}$.

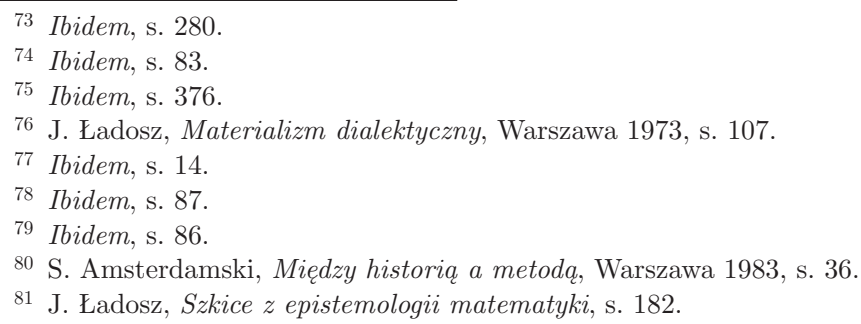


Ma to umożliwić zbadanie, jak ukształtowało się współczesne pojęcie intuicji matematycznej. Odtworzenie tego procesu winno być syntezą badań z obszaru logiki matematycznej, historycznych, psychologicznych, gdyż żadne z osobna nie jest w stanie w pełni wytłumaczyć powstania wiedzy matematycznej ${ }^{82}$. Aby uzyskać pożądane rezultaty, Ładosz postanowił włączyć do swojej koncepcji epistemologię matematyki Piageta, ze względu na jego bogatą, potwierdzoną empirycznie wiedzę z powyższych obszarów badawczych ${ }^{83}$, po czym zreinterpretować ją w duchu materializmu dialektycznego. W najkrótszym ujęciu teoria szwajcarskiego psychologa miała zakładać, iż

matematyka powstaje z rozwijających się działań „podmiotu poznawczego" zatopionego w przyrodniczym i socjalnym otoczeniu; na pewnym, empirycznie uchwytnym szczeblu rozwoju działania te, interioryzując się, przekształcają się w matematyczne operacje, będące wyrazem generalnych koordynacji działań podmiotu ${ }^{84}$

Tak więc podstawą poznania jest działanie, które wywołuje skojarzenia z marksistowskim pojęciem praktyki. Ładosz jednak krytycznie zauważył, że w teorii Piageta działanie może wypływać ,z wewnątrz" człowieka, a nie z jego społecznego otoczenia $^{85}$. Za kluczowe polski marksista uznał kategorię odwracalności działań i wyprowadzoną przez Piageta koncepcję zdobywania i utrwalania przez dzieci wiedzy logikomatematycznej za pomocą asymilacji — włączania danych ze świata zewnętrznego do istniejących struktur poznawczych; i akomodacji - tworzenia nowych struktur poznawczych w celu lepszej adaptacji do świata:

droga do powstania logicznych więzi pojęciowego myślenia, więzi o charakterze bezczasowym i implikacyjnym, wiedzie przez narastanie odwracalności działań przebiegających w czasie i mających przyczynowy charakter - materialnych, a następnie psychicznych ${ }^{86}$.

W działalności organizmu umiejętności wykonywania poszczególnych czynności wzrastają, na przykład poprzez obrót w tył i w przód w różnych wariantach zatrzymania, dziecko nabywa empirycznie świadomość 360, 180, 90 stopni itd. Dzieci, bawiąc się lub wykonując różne praktyczne zadania, dokonują za pomocą asymilacji i akomodacji (zawarte w każdym działaniu) zmian jakościowych w swojej świadomości. W ten sposób w ich umyśle „skonstruowana” zostaje abstrakcja konkretnych, praktycznych działań pod postacią pojęć, obiektów i symboli logikomatematycznych. Psychologiczne mechanizmy „odwracalności”, odpowiadające za przejście z pewnej ilości empirycznych operacji w konkretną umysłową jakość, Ładosz utożsamia z dialektycznym prawem negacji negacji (kumulacja wiedzy) ${ }^{87}$. Zatem:

\footnotetext{
82 Ibidem, s. 183-184.

83 Ibidem, s. 207.

84 Ibidem, s. 208.

85 Ibidem, s. 209.

86 Ibidem, s. 219.

87 Ibidem, s. 220-221.
} 
Zarówno logika formalna, jak i matematyka stanowią rezultat długotrwałego procesu wyodrębniania się w aktywności psychicznej w sposób coraz pełniejszych działań o charakterze ilościowym od działań w charakterze jakościowym ${ }^{88}$.

Odkrycia Piageta miały psychologiczny mechanizm złudzenia możliwości redukcji całej matematyki do prostej logiki ${ }^{89}$.

Z badań Piageta Ładosz wyciągnął następujące wnioski. Matematyka zawiera w sobie ruch, który powstaje ,z procesu kształtowania się działalności podmiotu wciąż nowych struktur koordynacji działań i rekonstruowania tych struktur, proces abstrakcji jest efektem przebudowy tych koordynacji, pojęcia i teorie matematyczne powstają z operacyjnej wiedzy umysłu"90. A więc konstrukcje matematyczne przestają mieć charakter duchowy i zyskują wymiar materialny, a materią tą jest ludzka działalność. Zatem:

Rzeczą możliwą jest odtworzenie procesu kształtowania się wiedzy matematycznej z rozwoju działań człowieka, z postępującego stosownie do wymagań zmiennych i zmienianego środowiska materialnego koordynacji tych działań, a następnie interioryzacji tych struktur. Koordynacja ta imituje ogólne transformacje materialnego świata ${ }^{91}$.

W ten sposób wiedza logikomatematyczna, choć niezawodna i stanowiąca według Ładosza wiedzę absolutną ${ }^{92}$, nie jest wcale przeciwstawna prawidłowościom materialnego świata ${ }^{93}$. W tym świetle hipoteza natywistyczna, zdaniem polskiego marksisty, wynika z rozerwania związku asymilacji i akomodacji, co prowadzi do założenia dziedziczności asymilacyjnych schematów działalności psychicznej ${ }^{94}$. Taką (błędną) hipotezę przyjął zresztą sam Engels, traktując umiejętności matematyczne jako nabyte ewolucyjnie ${ }^{95}$. Co więc sprawia, że wszyscy wiedzą, że $2+2=4$ ? Wyjaśnienie tego współpracą intelektualną zbioru jednostek nie wydaje się w sposób satysfakcjonujący wyjaśniać obiektywności praw logiki ${ }^{96}$. Jak tłumaczy Ładosz, praca umysłowa nie jest jakąś genetyczną formą ludzkiej praktyki, lecz wywodzi się od działalności produkcyjnej. Problematyczność genezy obiektywnych praw myśli nie umknęła Piagetowi, który z tego względu mimo bogatego materiału empirycznego pozostał przy, jak to określił Ładosz, „aprioryzmie funkcjonalnym”97. Sam Ładosz uznał, że da się skoordynować wyniki jego badań z badaniami historycznymi, podnosząc hipotezę upatrującą, ,wspólnej przyczyny powstawania pojęć i operacji logikomatematycznych oraz występowania odpowiadajaccych im schematyzmów w międzyludzkiej komunikacji językowej w historycznie kształtujących się ogólnych schematyzmach materialnych współdziałań ludzi, w ich kooperacji

\footnotetext{
88 Ibidem, s. 254.

89 Ibidem, s. 267.

90 Ibidem, s. 288.

91 Ibidem, s. 290.

92 J. Ładosz, Wielowartościowe rachunki zdań a rozwój logiki, s. 247-248.

93 J. Ładosz, Szkice z epistemologii matematyki, s. 290.

94 Ibidem, s. 293-308.

95 Ibidem, s. 210.

96 Ibidem, s. 334.

97 Ibidem, s. 355.
} 
wytwórczej”98, a zatem: „Pojęcia i operacje logikomatematyczne będą zinterioryzywanymi i zmentalizowanymi strukturami uprzednio skoordynowanych ogólnych struktur materialnego współdziałania społecznego"99.

Materialistyczno-dialektyczna interpretacja prowadzi do wniosku, że akomodacja imitująca jest wynikiem podwójnego procesu — „dostosowanie zinterioryzowanego działania do ogólnych, historycznie ukształtowanych struktur działania kolektywnego działania materialnego ludzi" i dostosowania tych struktur do transformacji świata zewnętrznego stanowiących podstawę historycznego zróżnicowania czynności jednostek uwikłanych we współdziałanie, które przynoszą użyteczne efekty. Akomodacja imitująca ma rekonstruować obrazowe schematy ,zintererioryzowanych działań", czynnych w psychice jednostki, umożliwiających ich intersubiektywną komunikację, która dokonuje się przez refleksyjną abstrakcję kolektywnego sposobu asymilowania świata. Zatem: „pojęcia logikomatematyczne są symbolami operacyjnymi ukonstytuowanymi przez imitującą akomodację ogólnych struktur sieci produkcyjnych współdziałań ludzi"100.

Pojęcia matematyczne, wedle rekonstrukcji polskiego marksisty, pojawiły się w wyniku stabilizacji struktur stosunków produkcji i wymiany. I tak liczba naturalna pojawiła się w toku koordynacji materialnych działań zachodzących w procesie wymiany towarów - proces wymiany ulega koordynacji, towary układane są w szeregi i stosy. Dowodzą tego badania historyczne radzieckich badaczy, między innymi Wajmana. Matematyka Babilończyków i Sumerów miała bowiem zastosowanie w buchalterii, a nie technicznym procesie produkcji. Zarówno w starożytności, jak i w średniowieczu wiedza matematyczna była popularna przede wszystkim wśród kupców ${ }^{101}$. Dlatego ułamki greccy matematycy traktowali jako coś paradoksalnego, będącego praktyczną specyfiką działalności kupieckiej. Dzielenie jedności na części było dla nich absurdalne, bo jedność była z zasady niepodzielna ${ }^{102}$. Do czasów kapitalistycznych wytwarzanie dóbr miało charakter indywidualny, więc operacje matematyczne rozwijały się tam, gdzie indywidualne wytwarzanie zaczęło być koordynowane za pomocą medium technologii, przykładowo przy wznoszeniu budowli, w nawigacji, przy wprowadzeniu nowych sposobów nawadniania związanych z astronomicznym pomiarem czasu (dlatego też trygonometria była wtedy częścią astronomii). Była to jednak matematyka czysto użytkowa.

Dopiero w XVI-XIX wieku rozpoczyna się proces uzgadniania wiedzy matematycznej z technicznym procesem produkcji ${ }^{103}$. Podział pracy wytwórczej podyktowany wymogami technologii miał miejsce w pełni dopiero w okresie manufaktury, a następnie rozwoju wielkiego przemysłu. Wcześniejsze zautomatyzowane już koordynacje czynności jednostki zostały poddane rekonstrukcji w kooperacji technicznej, a ich struktura została ujęta pojęciowo, a następnie teoretycznie. Doprowadziło to do dynamicznego rozwoju fizyki i nauk technicznych. Stąd też złudzenie,

\footnotetext{
98 Ibidem, s. 335.

99 Ibidem, s. 355.

100 Ibidem, s. 337.

101 Ibidem, s. 339.

102 Ibidem, s. 369.

103 Ibidem, s. 340-341.
} 
że matematyczne struktury powyższych koordynacji zostały wywiedzione z fizyki. Zaczęto wówczas odkrywać, że cała przyroda jest pełna takich zależności, w związku z czym zaczęły się rodzić poglądy o wyłącznej więzi matematyki z fizykalną działalnością człowieka i empirycznymi naukami przyrodniczymi, postrzegane następnie jako jedyna alternatywa apriorystycznych teorii wiedzy matematycznej. Wniosek z tego taki, że rację mają aprioryści uznający, iż techniczna działalność jednostek nie może być uznana za źródło powstania struktur matematycznych. Tworzą się one dopiero dzięki kolektywnej, technicznej kooperacji ${ }^{104}$. Ładosz na tej podstawie wysunął też interesującą hipotezę, że niedoskonałości antycznej matematyki brały się z niedoskonałości antycznego (niewolniczego) sposobu produkcji, którego upadłość pogrzebała również kooperację techniczną związaną w dużej mierze z rozwojem antycznej sztuki i organizacji militarnej ${ }^{105}$, która jak wiadomo, uległa na jakiś czas zapomnieniu w wiekach średnich. Ustalenia historyczno-matematyczne Ładosz wiąże z marksistowskimi badaniami nad historią gospodarczą, powołując się na ustalenia radzieckiego ekonomisty Nowożyłowa. Sposoby pomiaru nakładów i czasy pracy mają być a dekwat ny m odzwierciedleniem stanu rozwoju społecznych sposobów produkcji. Przykładowo zasada oszczędności pracy, która wydaje się uniwersalna, była stopniowo konkretyzowana i uświadamiana podczas przekształceń produkcji społecznej ${ }^{106}$. Ostatecznie więc Ładosz konkluduje, że

Logikomatematyczne pojęcia i operacje stanowią imitującą akomodację umysłową do generalnych struktur materialnej kooperacji międzyludzkiej, a za ich pośrednictwem — do ogólnych ilościowych transformacji świata. Taka jest istota wiedzy logikomatematycznej. Źródło tej wiedzy i jej pewności jest podmiotowo-przedmiotowe, wyraża ona bowiem prawa wspólne przyrodzie zewnętrznej, powiązaniom czynności jednostki oraz materialnym interakcjom społecznym. Prawa te zostają jednak uświadomione jako matematyczne nie wcześniej, nim staną się strukturą międzyosobniczych działań, nim dokona się przebudowa automatyzmów jednostki w skoordynowane społecznie działanie na przyrody ${ }^{107}$.

Nie powstają one w wyniku celowego badania tych struktur przez ludzi, to znaczy matematycy nie powinni badać socjologicznych czy ekonomicznych źródeł matematyki. Matematyka stwarza narzędzia do opanowania współzależności społecznych i przebudowania ich struktury pojawiającej się w komunikacji językowej, społecznej, w logice. Autonomiczność rozwoju matematyki jest względna, wynika z ,zapomnienia" dopasowania teorii matematycznych względem materialnej, historycznej rzeczywistości i jej przemian ${ }^{108}$. Nie ma żadnej wrodzonej czy nabytej intuicji konstrukcji matematycznej. Istnieje proces z jednej strony biologiczno-zmysłowy, z drugiej abstrakcyjno-pojęciowy, które w zespoleniu tworzą wiedzę matematyczną ${ }^{109}$. Ale zgodność odkryć matematycznych z kształtującymi się w odpowiednich epokach strukturami społecznej interakcji może być wykryta jedynie ex post. Inne podejście hamowałoby albo nawet uniemożliwiało badania matematyczne ${ }^{110}$.

\footnotetext{
104 Ibidem, s. 342.

105 Ibidem, s. 345.

106 Ibidem, s. 352.

107 Ibidem, s. 355.

108 Ibidem, s. 358.

109 Ibidem, s. 374.

110 Ibidem, s. 378.
}

Studia Philosophica Wratislaviensia, vol. XV, fasc. 4 (2020)

(C) for this edition by CNS 


\section{Uwagi końcowe}

Krytyczne uwagi Ładosza na temat logik wielowartościowych i prądów konstruktywistycznych pokrywaja się z krytyką tych tendencji w filozofii współczesnej $^{111}$, uzupełniając listę zarzutów o dodatkowe punkty. Jednak mimo niewątpliwego rozmachu jego liczaccych setki stron dzieł logikomatematycznych pozostał on ortodoksem w sensie przywiązania do „marksistowsko-leninowskiej” terminologii i schematów pojęciowych. Wszystkie wywody umotywowane są ,walką klas w filozofii", leninowską zasadą partyjności i zwalczaniem wszelkiej maści rewizjonistów „naiwnie” otwierajaccych podwoje marksizmu przed pozytywizmem logicznym ${ }^{112}$. Główne jego postulaty mają charakter defensywny i zręcznie łączą obronę autorytetu Arystotelesa i Lenina (Engels jest już krytykowany). Wszystkie przedstawione tu jego tezy zostały zatem przez polskiego marksistę wpisane w schemat podmiotowo-przedmiotowy, podział idealizm-materializm, zmodyfikowaną klasyczną definicję prawdy („prawda to zgodność wiedzy z rzeczywistością, która jest materialna w swej istocie"113), zakładającą jej względność, prócz „absolutnych” prawd matematyki i logiki, kategorię praktyki jako uniwersalnego kryterium i źródło tych prawd i leninowską teorię odbicia. Obowiązują w nich uznawane dziś za arbitralne założenia naukowego realizmu ontologicznego i epistemologicznego (które jednak wydają się niezbędne w działalności naukowej114, a zatem i w filozofii naukowej). Na kartach Wielowartościowych rachunków zdań nie brakuje też słynnych zwrotów o racjonalnych ,ziarnach” i ,jądrach".

W polskiej marksologii wysoko ceniona jest Siemka koncepcja różnicy epistemologicznej. Sprowadza się pokrótce do stwierdzenia, że ujmowanie problematyki poznania w ramach podziału idealizm-materializm, którego obie strony zawierają podział przedmiotowo-podmiotowy, jest wyrazem przedkantowskiego filozofowania rozsądkowego, opartym na „różnicy epistemicznej”"115. W tym sensie, jak zdaje się dowodzić Bednarek, „prawdziwie” marksistowską i dialektyczną filozofią jest ta, która likwiduje podział przedmiotowo-podmiotowy przy pomocy medium historycznej praktyki społecznej, która ustanowiona zostaje w centrum dialektycznej ontologii, usuwając podział na byt przyrodniczy i społeczny ${ }^{116}$. Na pierwszy rzut oka wojujący z idealizmem przez setki stron Ładosz wydaje się takim ,rozsądkowym" myślicielem. W rzeczywistości jednak jego prace wykazują szereg rewizji względem dogmatycznej filozofii marksistowskiej, rozdwajającej to, co przyrodnicze i materialne, od tego, co społeczne i zarazem „duchowe”. Odrzucał wulgarne

111 Zob. D. Cholewa, op. cit.; B. Czarnecka-Rej, Stosowalność logik wielowartościowych, „Filozofia Nauki" 58 [2] (2007), s. 75-93.

112 J. Ładosz, Wspótczesne formy walki materializmu z idealizmem, Warszawa 1965, s. 41, 63-82.

113 J. Ładosz, Materializm dialektyczny, s. 147.

114 S. Butryn, Czynnik podmiotowy w idei ontologicznego realizmu naukowego, „Przegląd Filozoficzny" 63 (2007), s. 127-138.

115 M. Siemek, Hegel i różnica epistemiczna, „Nowa Krytyka” 16 (2004), http://filozofiauw.wdfiles. com/local--files/teksty-zrodlowe/Marek\%20Jan\%20Siemek\%20-\%20Hegel\%20i\%20r\%C3\%B3\%C5\%BCnica\%20epistemologiczna.pdf (dostęp: 28.08.2020).

116 J. Bednarek, Różnica epistemologiczna i cięcie sprawcze, [w:] Feministyczne nowe materializmy: usytuowane kartografie, O. Cielemięcka, M. Rogowska-Stangret (red.), Lublin 2018, s. 89-108. 
radzieckie potępienia idealizmu w matematyce i opieranie się na cytatach klasyków, dominację nauk przyrodniczych i dominację diamatu nad materializmem historycznym $^{117}$. Deprecjonował przyrodocentryczne twierdzenia Engelsa. Twierdził, że współcześnie podziały ontologiczne są pochodne względem metodologicznych norm postępowania poznawczego, umieszczając w centrum materializmu dialektycznego „materialną działalność człowieka” jako fundamentu poznania społecznego i przyrodniczego ${ }^{118}$. W swoich pracach potwierdził te deklaracje, czyniąc z ludzkiej działalności ontologiczny fundament wiedzy logikomatematycznej. Analogicznie ujmował w tych pracach prawdę jako „zgodność odbicia materialnego świata w pojęciowym myśleniu ludzkim z tym światem, zgodności osiąganej, sprawdzanej i korygowanej w toku społeczno-produkcyjnej ludzkiej praktyki"119. Wydaje się, że w tych czasach faktycznie filozofował w „polu epistemologicznym” mimo pewnych niejasnych sformułowań i ortodoksyjnej terminologii.

Nie wiadomo dlaczego Ładosz wycofał się ze swoich badań logikomatematycznych oraz definicji i hipotez stawiających społeczną działalność w centrum poznania. Szkoda, gdyż jego wykład jest bliski rozumieniu logiki dialektycznej i roli społecznej działalności, prezentowanej w pracach najbardziej znanego radzieckiego filozofa Iljenkowa oraz jego uczniów reprezentujących podejście aktywistyczne w marksizmie, które zyskało uznanie zachodnich badaczy ${ }^{120}$. Odnosząc się do problemu wiedzy matematycznej na łamach Materializmu dialektycznego, Ładosz nie wspomina o swojej hipotezie, stwierdzając jedynie, że problem ten został wyjaśniony w badaniach socjologicznych i antropologicznych ${ }^{121}$. W kolejnych latach poświęca się refleksji społeczno-politycznej, różnie ocenianej. Być może wyciągnął praktyczny wniosek ze swoich tez i uznał, że skoro działalność ludzka ma centralne znaczenie, należy przejść do materializmu historycznego.

\section{Bibliografia}

Ajdukiewicz K., Zmiana i sprzeczność, [w:] idem, Język i poznanie, t. 2, Warszawa 1965, s. $90-106$.

Amsterdamski S., Między historia a metoda, Warszawa 1983.

Bednarek J., Różnica epistemologiczna i cięcie sprawcze, [w:] Feministyczne nowe materializmy: usytuowane kartografie, O. Cielemięcka, M. Rogowska-Stangret (red.), Lublin 2018, s. 89-108.

Butryn S., Czynnik podmiotowy w idei ontologicznego realizmu naukowego, „Przegląd Filozoficzny" 63 (2007), s. 127-138.

Cholewa D., Trzy argumenty przeciwko konstruktywizmowi matematycznemu, „Filozofia Nauki" 72 [4] (2010), s. 77-95.

117 J. Ładosz, Wspótczesne formy walki materializmu z idealizmem, s. 6-13.

118 Ibidem, s. 27-58.

119 J. Ładosz, Wielowartościowe rachunki zdań a rozwój logiki, s. 219.

120 Zob. The Practical Essence of Man, V. Oittinen, A. Maidansky (eds.), Chicago 2017; E. Iljenkow, Logika dialektyczna, Warszawa 1973.

121 J. Ładosz, Materializm dialektyczny, s. 135-136. 
Czarnecka-Rej B., Stosowalność logik wielowartościowych, „Filozofia Nauki” 58 [2] (2007), s. $75-93$.

Engels F., Anty-Dühring, Warszawa 1948.

Engels F., Dialektyka przyrody, Warszawa 1953.

Gadacz T., Krytyka materializmu dialektycznego w pracach Kazimierza Kłósaka, „Znak” 350 (1984), s. 33-46.

Iljenkow E., Logika dialektyczna, Warszawa 1973.

Lemhoff R., Intuitionism in the Philosophy of Mathemathics, https://plato.stanford. $\mathrm{edu} / \mathrm{entries/intuitionism/ \# Bro.}$

Luty W., Sprzeczności logiczne a dialektyczne, http://smp.edu.pl/sprzecznosci-logicznea-sprzecznosci-dialektyczne/\#sdfootnote5sym.

Ładosz J., Wielowartościowe rachunki zdań a rozwój logiki, Warszawa 1961.

Ładosz J., Wspótczesne formy walki materializmu z idealizmem, Warszawa 1965.

Ładosz J., Szkice z epistemologii matematyki. Matematyka jako działalność konstruktywna, Warszawa 1968.

Ładosz J., Materializm dialektyczny, Bydgoszcz 1973.

Łubnicki N., Teoria poznania materializmu dialektycznego, „Annales Universitatis Mariae Curie-Skłodowska Lublin Polonia Sectio F" 1-2 (1946), s. 121-186.

Łukasiewicz J., O zasadzie sprzeczności u Arystotelesa, Warszawa 1987.

Łukasiewicz J., Sylogistyka Arystotelesa z punktu widzenia wspótczesnej logiki formalnej, tłum. A. Chmielewski, Warszawa 1988.

Mysłek W., Eadosz, https://web.archive.org/web/20100416063357/http://www.smp. republika.pl:80/polemiki/Ladosz.htm.

Plechanow J., Podstawowe zagadnienia marksizmu, Warszawa 1949.

The Practical Essence of Man, V. Oittinen, A. Maidansky (eds.), Chicago 2017.

Schaff A., Wstę do teorii marksizmu, Warszawa 1947.

Siemek M., Hegel i różnica epistemiczna, „Nowa Krytyka” 16 (2004), s. 73-84.

Stalin J., O materializmie dialektycznym i historycznym, [w:] idem, Zagadnienia leninizmu, Warszawa 1949 .

Vucinich V., Soviet Mathematics and Dialectics in the Stalin Era, „Historia Mathematica" 27 (2000), s. 54-76.

Vucinich V., Soviet Mathematics and Dialectics in the Post-Stalin Era: New Horizons, „Historia Mathematica” 29 (2002), s. 13-39.

Walicki A., Marksistowska filozofia w PRL w świetle osobistych wspomnień, „Przegląd Filozoficzny" 63 [3] (2007), s. 247-276.

Woleński J., From Controlled Liberalism to Real Pluralism. The Development of Philosophy in Poland at the End of the Communism Era, [w:] 20 Years After the Collapse of Communism, N. Hayoz, D. Koleva, D. Jesien (red.), Bern 2011, s. 559-572. 